\title{
Wind Energy Generation and Assessment of Resources in India
}

\author{
Vishakha Tank, Jignasha Bhutka*, T. Harinarayana \\ Gujarat Energy Research \& Management Institute (GERMI), Gandhinagar, India \\ Email: *jignasha.b@germi.res.in
}

How to cite this paper: Tank, V., Bhutka, J. and Harinarayana, T. (2016) Wind Energy Generation and Assessment of Resources in India. Journal of Power and Energy Engineering, 4, 25-38.

http://dx.doi.org/10.4236/jpee.2016.410002

Received: July 19, 2016

Accepted: October 24, 2016

Published: October 27, 2016

Copyright $\odot 2016$ by authors and Scientific Research Publishing Inc. This work is licensed under the Creative Commons Attribution International License (CC BY 4.0).

http://creativecommons.org/licenses/by/4.0/ (c) (i) Open Access

\begin{abstract}
The gap between energy demand and its generation is constantly widening. People have started giving more emphasis on renewable sources of energy. This paper presents the estimation of potential for wind energy generation maps based on fixed wind turbine capacity. Although wind energy has developed substantially in recent years, we have only wind speed and wind potential density maps. Our attempt here is to generate wind energy generation potential maps. Major step in achieving this goal is modeling of wind energy conversion system using TRNSYS software. The model consists of three main components namely the weather, the turbines and energy conversion parameters. The weather data are provided from the meteorological database, namely Meteonorm. The simulated output is compared with actual wind generation of wind farms. After comparing our model results with the existing wind energy generation data, we have extended to compute the wind energy generation for all locations in India. For simulation, 4691 locations are identified considering $0.25^{\circ}$ $\times 0.25^{\circ}$ interval. The energy generation simulated data are compiled and developed into maps that are useful to all wind energy developers. The data generated and presented in the form of maps are for all the 30 states of India.
\end{abstract}

\section{Keywords}

Wind Energy Generation Map, Wind Turbine, TRNSYS, Simulation, India

\section{Introduction}

The exponential increase in utilization of electrical energy and the constant decrease in conventional sources of energy have led to huge gap between demand and supply of electrical energy. This has led the people to switch over to renewable sources of energy such as solar, wind, biomass, geothermal, etc. According to International Energy Agency, India and China are likely to consume more than 28 percent of the world total energy 
by 2030 . Renewable energy sources must contribute to a significant amount to protect our environment as they are least pollutants [1]. According to a report (REN21's 2016), renewable sources contributed 23.7 percent of generation of electricity in 2015. This energy consumption is divided as 8.9 percent from traditional biomass, 4.2 percent from heat energy (solar, geothermal and modern biomass), 3.9 and 2.2 percent from hydroelectricity and wind respectively [2]. The Government of India has set a target for total renewable capacity as $175 \mathrm{GW}$ by 2022. It includes $60 \mathrm{GW}$ from wind, $100 \mathrm{GW}$ from solar, $10 \mathrm{GW}$ from biomass and $5 \mathrm{GW}$ from small hydro power [3].

Among the various renewable sources of energy, wind is one of the most important sources and has widely gained attention in recent years. Although people harnessed energy from wind since ancient times, it was in different forms. Wind turbines were previously used for pumping water, grinding grains, etc. in some parts of the world before they are used for power generation [4].

Wind is considered as a promising alternative for power generation because of its environmental and economic benefits such as reduced greenhouse gas emission, reduced fuel cost and provides clean and cost effective energy [1]. Additionally, wind energy is an optimum choice due to relatively short installation time, easy operation and maintenance with reduced natural habitat disturbance compared to conventional energy source.

The factors that influence the energy produced by wind energy generators (WTG) over a particular location include: 1) power curve of the wind turbine for different wind speed, 2) good distribution of wind velocity within a location and 3) strength of prevailing wind speed in the area. The total energy generated by WTG over a period can be calculated by summation of energies corresponding to all operational wind speed [5]. The State-wise Cumulative Capacity until March 2016 is shown in Table 1.

Our study presents an approach to develop wind energy generation map based on a typical wind turbine size and also presents a method of wind resource assessment in India. The selection of a particular wind turbine size is chosen in our study is based on

Table 1. Cumulative capacity of different states [6].

\begin{tabular}{cc}
\hline State & Total Cumulative Capacity $(\mathrm{MW})$ up to March 2016 \\
\hline Tamil Nadu & 7652.6 \\
Maharashtra & 4671.4 \\
Gujarat & 4031.0 \\
Rajasthan & 3995.1 \\
Karnataka & 2878.7 \\
Madhya Pradesh & 2171.6 \\
Andhra Pradesh & 1393.9 \\
Kerala & 43.5 \\
Telangana & 77.7 \\
Others & 4.3 \\
Total & $26,919.8$ \\
\hline
\end{tabular}


the majority usage of a wind turbine in the country. Based on this criterion, $0.8 \mathrm{MW}$ turbine is preferred in our study.

Three software's are used in the development of wind energy generation map. They are: a) Meteonorm, b) TRNSYS and c) Surfer. Meteonorm is a meteorological database that gives access to meteorological data for every location in the world that can be used in a variety of applications [7]. It contains worldwide weather data that can be retrieved in more than 35 formats. TRNSYS (Transient System Simulation Tool) is user-friendly graphical based software. It is used to simulate the behavior of transient systems [8]. Surfer is a powerful contouring, gridding and three dimensional surface mapping software that mainly runs under Microsoft Windows [9].

\section{Materials and Methods}

The methodology used in this study is to evaluate the wind energy potential conducted by a series of steps. First, the wind data is collected from a weather database and then a reference turbine model is selected followed by development of wind power conversion in TRNSYS software.

\subsection{Collection of Wind Speed Data}

As discussed before and above the wind speed data for our study are taken from a meteorological database-Meteonorm. It gives weather information at a universally accepted reference data collection from a height of 10 meters. The database provides an average value collected over a period of 10 years. The data is retrieved in a standard TMY2 format that is also the format used by TRNSYS.

\subsection{Selection of a Reference Wind Turbine Model}

The annual average wind speed of India varies from 6 to $7 \mathrm{~m} / \mathrm{s}$. For this reason mostly class II and III wind turbines are used in our country. For assessment, a wind turbine from Enercon model of E-53 of $800 \mathrm{~kW}$ is chosen. This turbine size is selected because of the following reasons: 1) it represents the size that is most often used in the nation 2) it comes from a manufacturer that is known for its high quality 3) this turbine has a standard hub height of 75 meters that is widely being used [10]. More details on the technical parameters of the selected wind turbine are shown in the Table 2. (Source: Enercon Product Brochure)The power curve is a graph showing wind speed versus power output of the chosen turbine as shown in Figure 1. There are three main points on this curve: 1) cut-in speed; 2) rated speed and 3) cut-off speed. Here, the cut-in speed is $3 \mathrm{~m} / \mathrm{s}$ at this speed turbine starts to deliver power. On rated speed wind turbine can give constant rated power output and cut-off speed beyond which the turbine is not allowed to deliver power and stop rotating wind turbine to protect against storm. If wind speed is increasing $3-13 \mathrm{~m} / \mathrm{s}$, power output also increasing cube of wind speed. Figure 2 shows the image of a wind farm in Gujarat. It is the first wind farm in India. It is located near the west coast $4 \mathrm{~km}$ from Mandvi. The narrow strip is of $1.5 \mathrm{~km}$ length and $55 \mathrm{~km}$ breadth [11]. It was established in 1985 with a total capacity of $1.1 \mathrm{MW}$. 
Table 2. Technical specifications of enercon E-53.

\begin{tabular}{cc}
\hline Parameter & Value \\
\hline Rated power & $800 \mathrm{~kW}$ \\
Rotor diameter & $52.9 \mathrm{~m}$ \\
Hub height & $75 \mathrm{~m}$ \\
No. of blades & 3 \\
Swept area & $2198 \mathrm{sq} \cdot \mathrm{m}$. \\
Cut-in speed & $3 \mathrm{~m} / \mathrm{s}$ \\
Rated wind speed & $13 \mathrm{~m} / \mathrm{s}$ \\
Cut-off speed & $28-34 \mathrm{~m} / \mathrm{s}$ \\
\hline
\end{tabular}

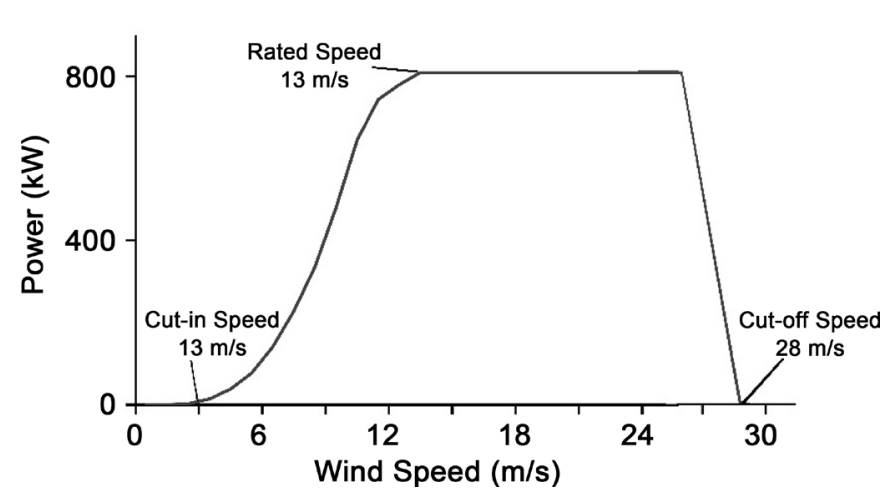

Figure 1. Power curve of $0.8 \mathrm{MW}$ wind turbine.

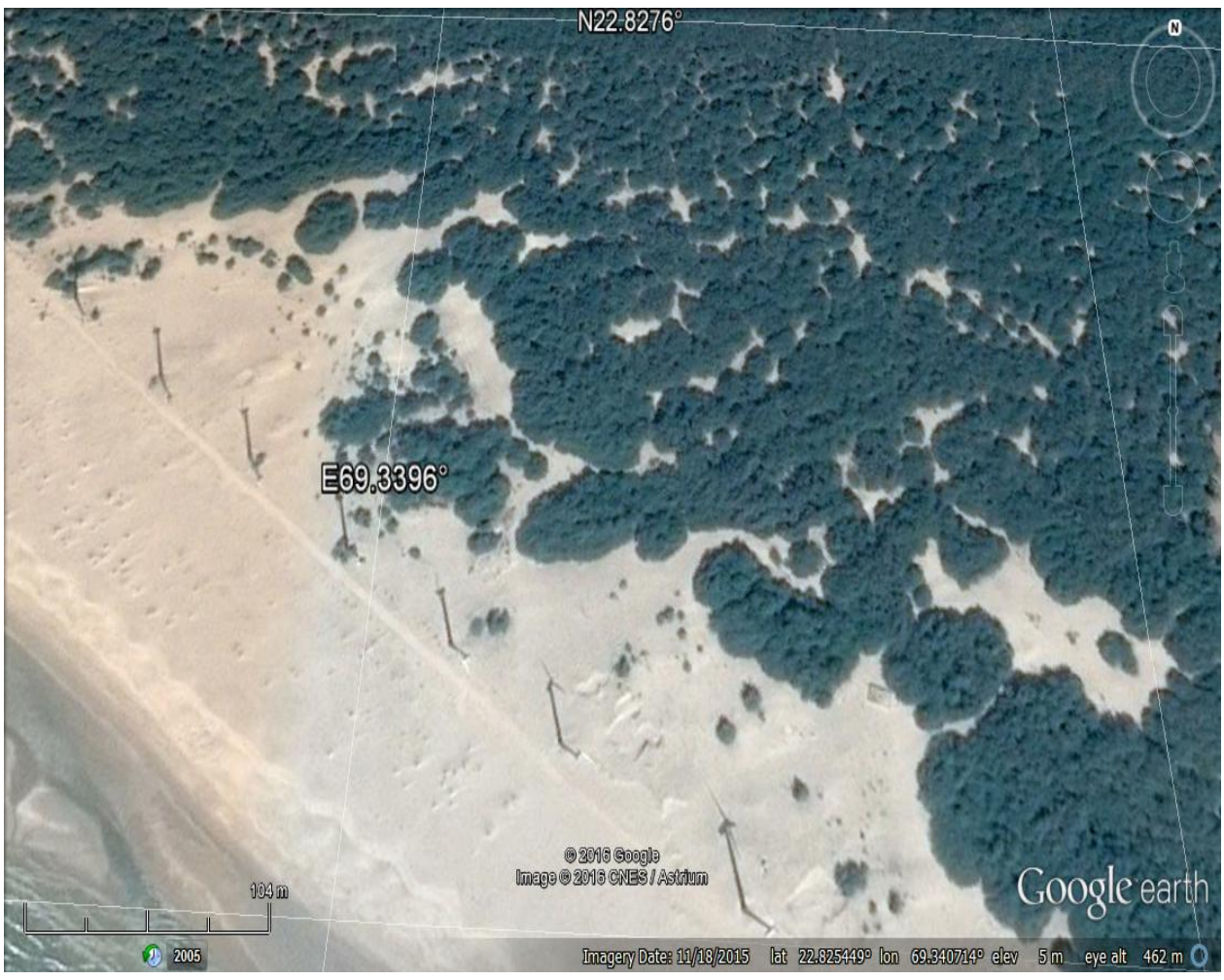

Figure 2. Google Earth image of wind farm at Mandvi, Gujarat (https://www.google.com/earth/). 


\subsection{Wind Calculation}

Wind is not constant but varies with time. The variation of wind speed with height is called wind shear. It necessitates the need to convert the recorded wind speed to the height of the turbine used. This conversion is achieved using the standard wind profile power law. This power law is widely used for wind resource assessment where wind speed for various heights is retrieved from the standard recorded wind data. The wind profile power law relationship can be expressed as

$$
v_{z}=v_{0}\left(\frac{z}{z_{0}}\right)^{\alpha}
$$

where, $v_{z}$ is the wind velocity at desired height $(\mathrm{m} / \mathrm{s})$,

$v_{0}$ is wind velocity at reference hub height $(\mathrm{m} / \mathrm{s})$,

$z$ is the desired height $(\mathrm{m})$,

$z_{0}$ is the reference hub height of turbine $(\mathrm{m})$.

The exponent is an empirically derived coefficient that varies depending upon the stability of the atmosphere. Generally, the coefficient is taken as $1 / 7$ or 0.143 for wind resource assessment. Thus, this value of coefficient is chosen for our study [11]. As the wind speed varies with time and place, power from the wind at a particular location also varies. The theoretical power from wind is calculated using the following equation [12].

$$
P=C_{p} \rho A V^{3}
$$

where, $P$ is the power extracted from wind in Watts, $\rho$ represents the air density, generally taken as $1.225 \mathrm{~kg} /$ cubic $\mathrm{m}$. The swept area of the rotor is represented by A in sq.m. and $V$ is the wind velocity in $\mathrm{m} / \mathrm{s}$. The parameter $C_{p}$ is called the power coefficient. It is the ratio of power output produced to the power available to the wind. No wind turbine can convert more than 59.3 percent of the kinetic energy to mechanical energy to turn a rotor. This is known as Betz limit and it is the theoretical maximum power coefficient for any wind turbine. For a good turbine it is in the range of $35 \%-45 \%$ [13].

\subsection{TRNSYS Model of Wind Energy Conversion}

The model used for converting kinetic energy of wind to electrical energy in TRNSYS is shown in Figure 3.

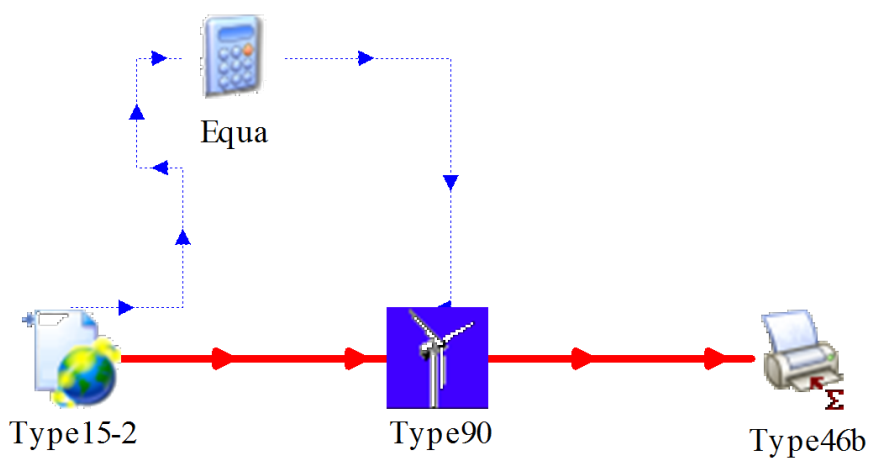

Figure 3. TRNSYS model of wind energy conversion system. 
In the model presented the input is meteorological data in TMY2 format from Meteonorm. This information is then fed to the wind turbine component named Type- 90 in TRNSYS. The turbine has the same technical specification as that of the Enercon E-53 model. The output of turbine gives generated power in the units of Watts read using Printegrator or Type-46b component. In addition to these components, an equation that converts the atmospheric pressure from the units of atm to $\mathrm{Pa}$ is used. It is inserted between the weather data and the wind turbine component.

\subsection{Mapping the Wind Energy Generation Data}

For mapping the wind energy generation, the essential step is to collect the wind data of the desired location. For this purpose, data is collected for the entire country at 4691 locations. They are chosen in a grid manner of $0.25^{\circ} \times 0.25^{\circ}$ station interval. This data is then contoured using Surfer for developing the wind energy generation maps.

\section{Results and Discussion}

In the system, the simulation control card is adjusted for one year (8760 hours) with a time interval of 0.125 hour. Figure 4 shows the simulation output with generated power plotted on left $\mathrm{Y}$-axis and the wind speed on right $\mathrm{Y}$-axis as a function of time.

The developed model has been validated with actual data of wind energy at a few locations. This is clearly depicted as shown in Figure 5. It compares the actual energy generated at wind farm with the simulated energy at that particular location using the TRNSYS model. It can be seen that a maximum of 10 percent deviation between actual and simulated energy. It means our model provide approximately correct result of energy generation [14].

After validation, the next step is to create maps of energy generation for different lo-

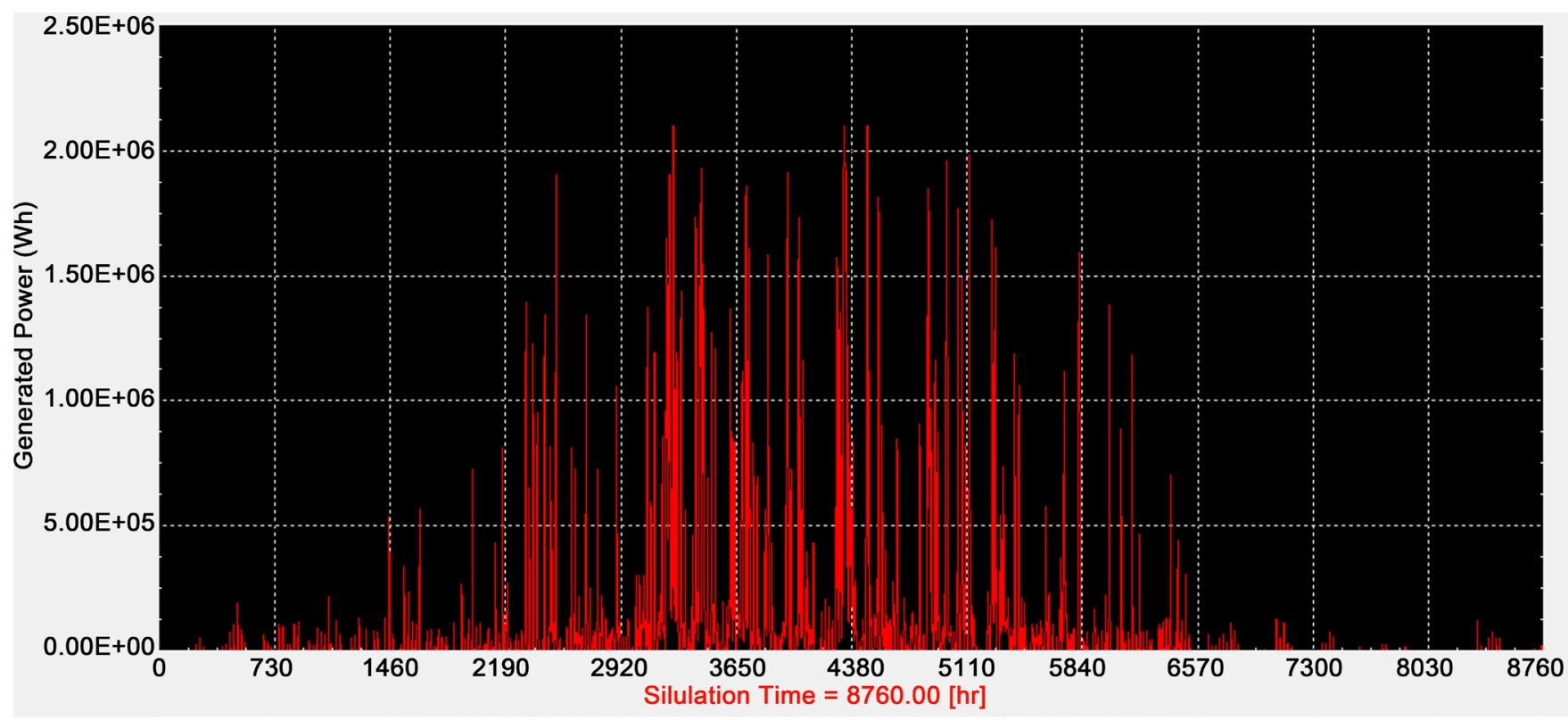

Figure 4. TRNSYS simulation of the wind energy conversion model. 


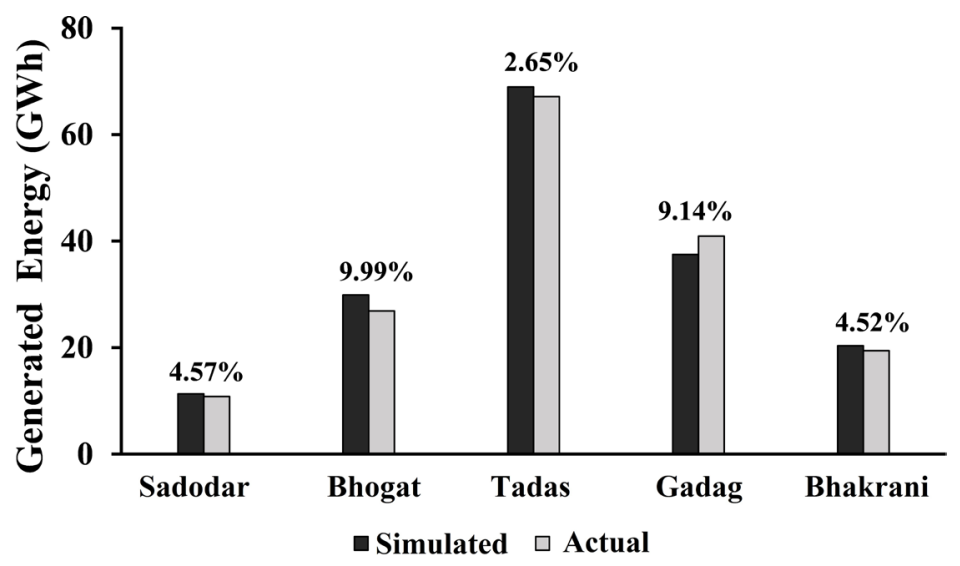

Figure 5. Comparison of actual and simulated energy generation, Deviation is shown in percentage.

cations. Surfer 10 software is used for this purpose [9]. For map generation, the same model with some parameters is used to calculate energy generation for the entire country with 0.25 degree grid interval. Accordingly, the wind energy generation for 4691 locations is computed and contoured. The illustrated Figure 6(a), Figure 6(b) and Figure 7 show the annual wind energy generation of all the states and also for the entire country. A detailed general description on generation of each state is provided in Table 3.

From the maps, it is visible that some states like Gujarat, Rajasthan, Tamil Nadu, Karnataka, Kerala, Maharashtra, Madhya Pradesh and Uttar Pradesh have higher energy generation than other states. Also it is observed that the wind speed is higher during May to August. Accordingly, there is higher energy generation in these months. However, the other months have relatively lower energy generation due to low wind speed. In general, the overall annual generation in India ranges till $1600 \mathrm{MWh}$.

It is well known that as we go higher from the ground level, wind velocity increases with increasing altitudes. As a result, some elevated areas have higher energy generation due to greater wind speed. For example, Deccan Plateau is elevated at $600 \mathrm{~m}$ and inclined towards south western part of India. This is the reason for higher generation in southern states. It is also clearly depicted that the western part of Madhya Pradesh has higher energy generation due to the presence of Satpura range of hills. There is a sudden change in energy generation near this region in the form of a straight line because of the presence of lower elevation surrounding the range of hills. Wind power density map of India is shown in Figure 8. As can be seen, there are some regions showing no wind density. But from our study some power generation is possible as shown in Figure 7 , although it is a low power generation area.

\section{Conclusion}

Considering 0.8 MW (Enercon E-53) wind turbine as a reference model, wind energy conversion system is designed and simulated in TRNSYS. The system's simulated generation output is compared with the actual data for a few wind farms. The deviation 

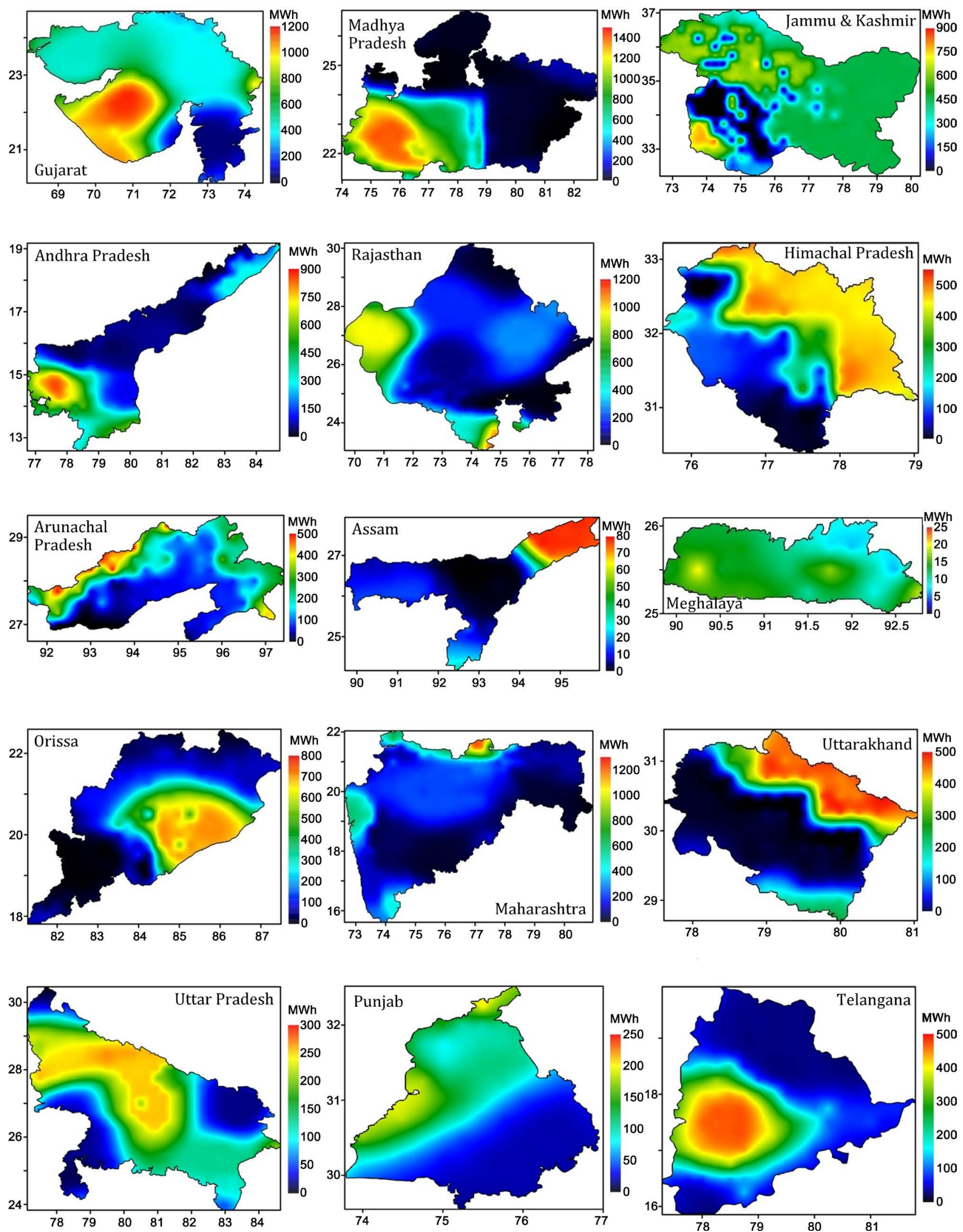

(a) 

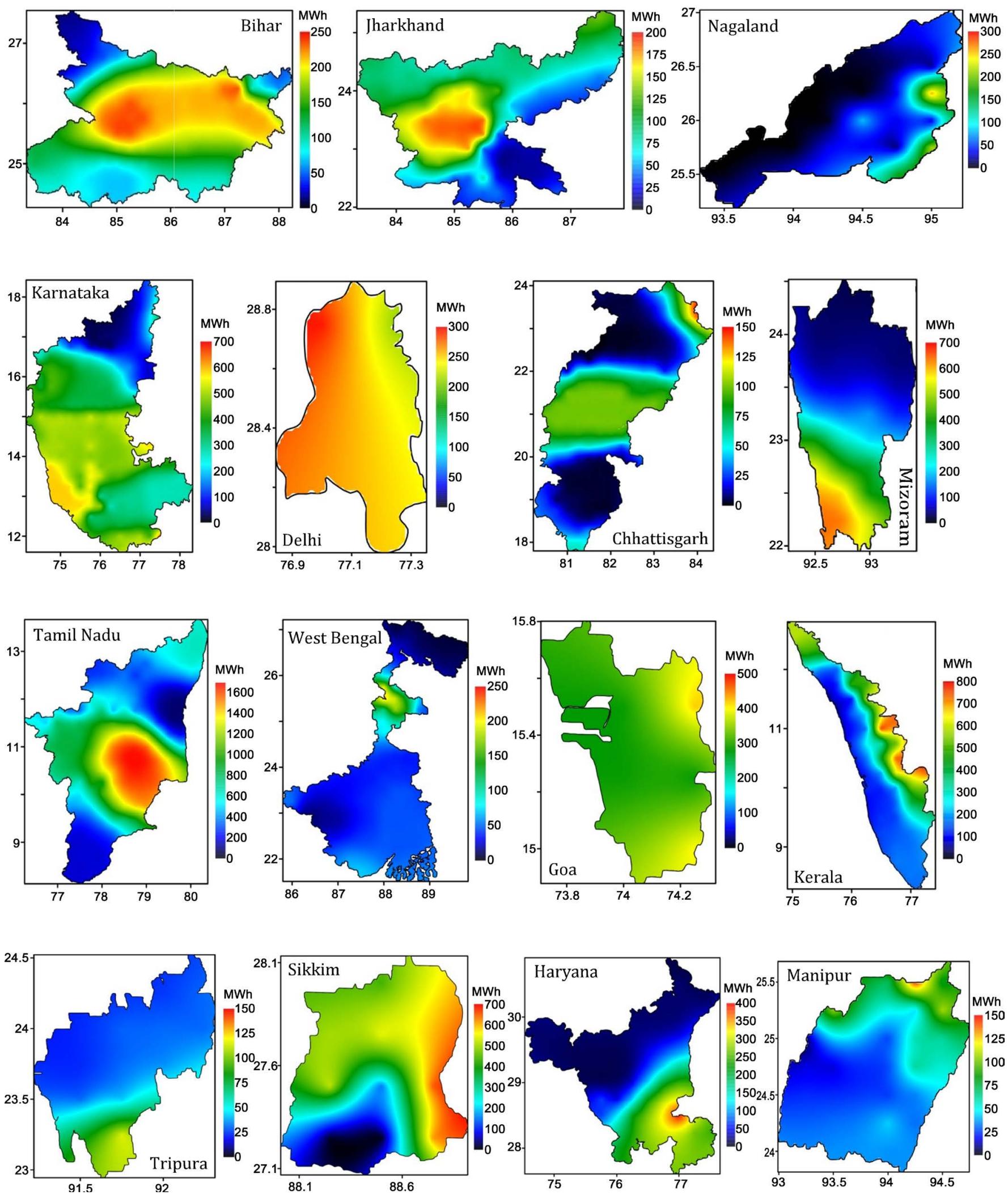

(b)

Figure 6. Annual state-wise energy generation maps of India [9]. 


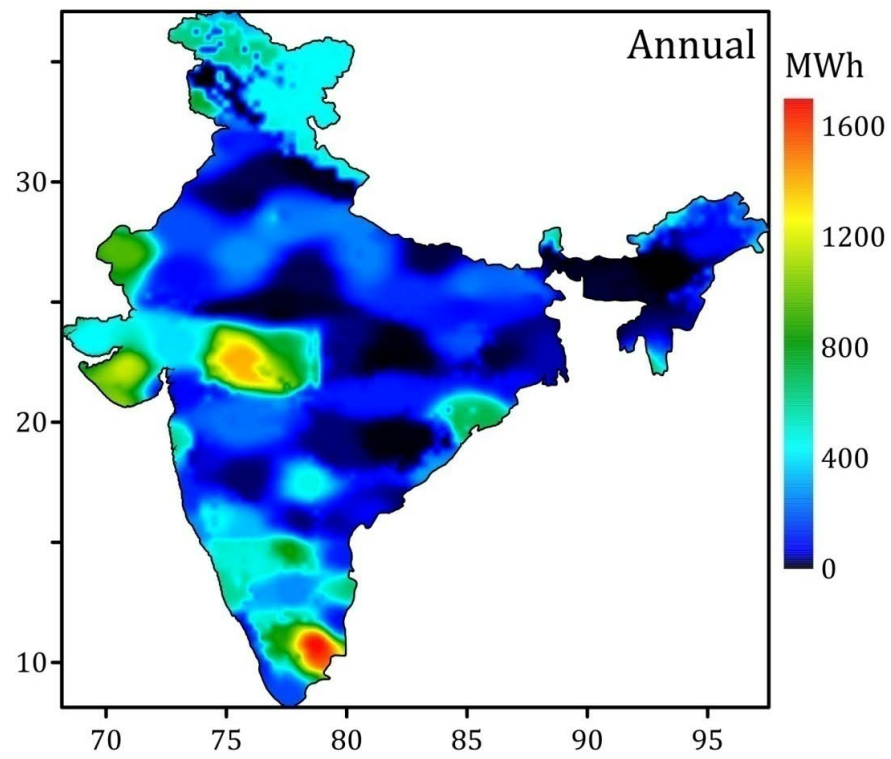

Figure 7. Annual wind energy generation map of India [9].

Table 3. District wise generation of all states of India.

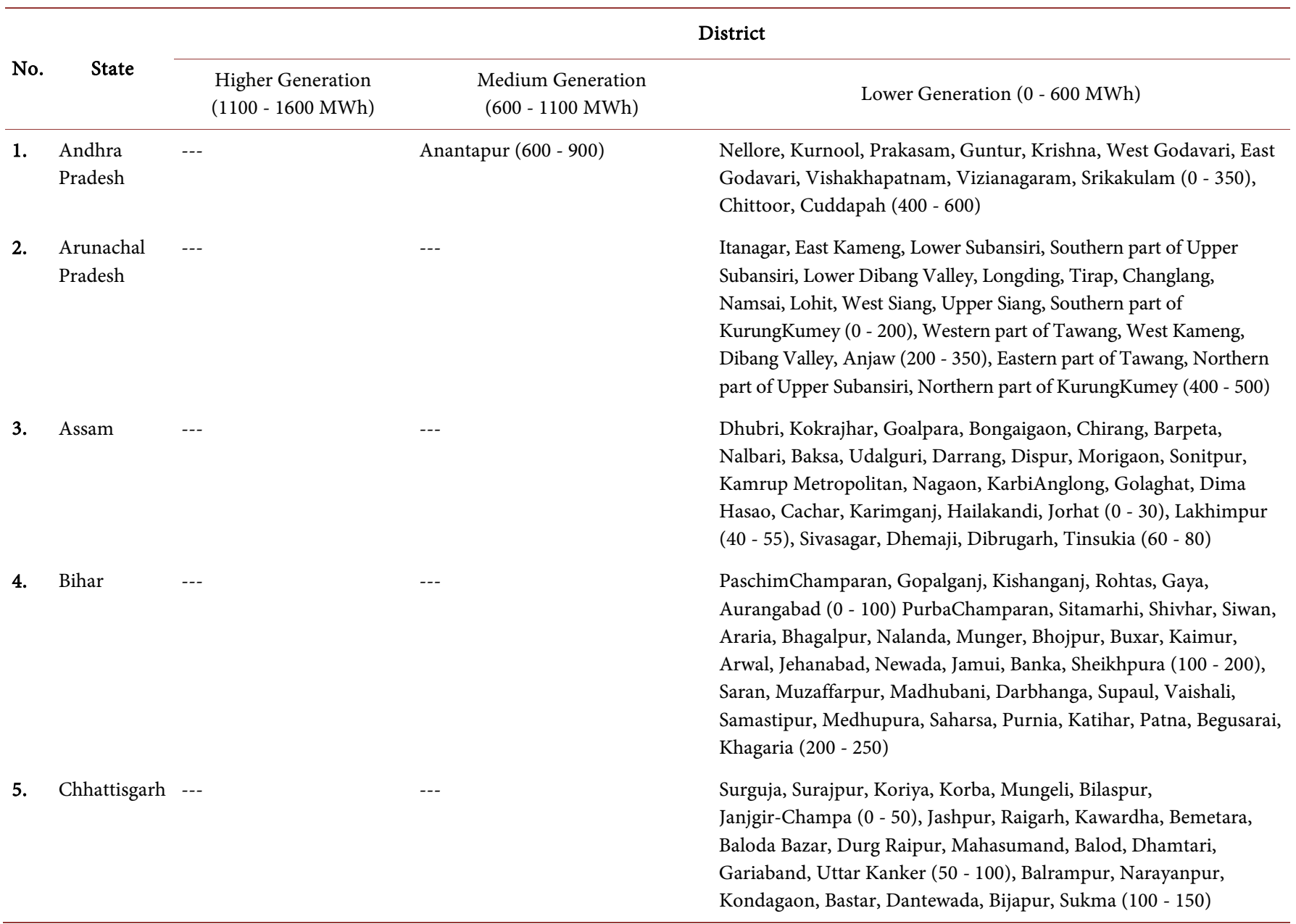




\section{Continued}

\begin{tabular}{llll}
\hline 6. & Delhi & --- & -- \\
7. Goa & --- & -- \\
8. Gujarat & --- & $\begin{array}{l}\text { Surendranagar, Botad, Dahod, } \\
\text { Rajkot, Jamnagar, Amreli, } \\
\\
\end{array}$ \\
& & Junagadh, GirSomnath, \\
& Porbandar, DevbhumiDwarka, \\
& & Chhota Udaipur $(900-1200)$
\end{tabular}

9. Haryana --- ---

10. Himachal ---

Pradesh

11. Jammu \& --

Kashmir

Rajouri (750 - 900)

12. Jharkhand ---

13. Karnataka -.-

14. Kerala ---

15. Madhya

Pradesh

Ratlam, Jhabua, Alirajpur, Southern part of Mandsaur, Dhar, Indore, Ujjain, Dewas, Khargone, Khandwa, Burhanpur (1100 - 1500)

16. Maharashtra ---

17. Manipur $---$

18. Meghalaya --Agar-Malwa, southern part of Rajgarh, Sehore, Bhopal, Lower Raisen, Harda, Betul, Western Chhindwara, Shajapur (700 1100)

Palghar, Thane, Upper Raigarh, Upper Nandurbar (600 - 1000), Upper Amravati (1000 - 1200)
Entire district $(200-300)$

All districts $(0-500)$

Banaskantha, Patan, Aravalli, Mahisagar, Sabarkantha, Mehsana, Ahmedbad, Gandhinagar, Kheda, Anand, Vadodara, Narmada, Bharuch, Surat, Tapi, Navsari, Valsad, The Dangs, Bhavnagar, PanchMahal, Kutch(0 - 600)

Panchkula, Ambala, Yamunanagar, Kurukshetra, Karnal, Kaithal, Jind, Fatehabad, Sirsa, Hisar, Bhiwani, Panipat (0 - 300), Jhajjar, Gurgaon, Faridabad, Mewat (300 - 400),

Sonipat, Rohtak, Mahendranagar, Palwal (175 - 300)

Una, Bilaspur, Hamirpur, Solan, Kangra, Shimla, Mandi, Central and south of Chamba, Western border of Kullu (0 - 200), Lahul and Spiti, Kinnaur, North eastern part of Chamba (400 - 600), Remaining all parts of Kullu (200-400)

Bandipora, Kupwara, Ganderbal, Baramulla, Badgam, Pulwama, Anantnag, Doda, Ramban, Udhampur, Samba, Kathua, Jammu (0 400), Leh (Ladakh), Kargil, Srinagar, Kishtwar, Reasi, Punch (400 700)

Dumka, Jamtara, Dhanbad, Bokaro, East Singhbhum, West Singhbhum, Jamshedpur, SeraikelaKharswan, Chaibasa (0 - 75), Hazaribag, Ramgarh, Ranchi, Khunti, Lohardaga, Latehar (125 200), Sahibganj, Godda, Pakaur, Deoghar, Giridh, Koderma, Chatra, Palamu, Garhwa, Simdega (75 - 125)

Bidar, Gulbarga, Remaining parts of Bijapur, Yadgir, Eastern part of Raichur (0 - 250), Karwar, Haveri, Chitradurga, Devangere, Shimoga, Udupi, Dakshin Kannada, Chikmagalur, Hassan, Kodagu, Chamarajanagar, Upper part of Tumkur (500 - 700), Southern part of Bijapur, Western part of Raichur, Bagalkot, Belgaum, Gadag, Dharwad, Kopal, Bellary, Lower part of Tumkur, Bangalore, Mysore, Kolar, Chikkaballapura, Mandya, Channapatna (250 - 500)

Kannur, Kozhikode, Remaining Malappuram, Western Palakkad, Thrissur, Ernakulam, Kottayam, Alappuzha, Pathanamthitta, Kollam, Thiruvananthapuram (0 - 300), Kasaragod, Wayanad, eastern Malappuram, Western part of Idukki (300 - 550)

Remaining all districts $(0-500)$

Remaining all districts $(0-600)$

Lower Ukhrul, Lower Senapati, Remaining all districts, Upper Ukhrul, Upper Senapati, North part of Tamenglong, Upper Senapati

Ri-Bhoi, West Jaintia Hills (0 - 10), Central part of West Garo Hills (20 - 25), Remaining all districts $(10-20)$ 


\section{Continued}

19. Mizoram

20. Nagaland $\cdots$

21. Orissa $--$

22. Punjab

23. Rajasthan ---

24. Sikkim

Eastern Gangtok, Eastern Mangan(500 - 700)

25. Tamil Nadu Karur, Tiruchirappalli, Upper Sivaganga, Thanjavur, Ariyalur, Pudukkottai, Thiruvarur, Lower Cuddalore, Perambalur (1200 - 1600)

26. Telangana

27. Tripura

28. Uttar Pradesh
Upper Jodhpur, Upper Banswara, Upper Pratapgarh, Lower Jhalawar (700 - 900), Jaiselmer, Western border of Barmer, Lower Banswara, Lower Pratapgarh (900 -1200)

Western Gangtok, Remaining Mangan, Upper Geizing (300 500)

Coimbatore, Erode, Namakkal, Upper Dindigul, Upper Madurai, Nagapattinam $(700$ - 1200)
Remaining districts $(0$ - 300)

Remaining all districts $(0$ - 700)
Lawngtlai, Lower Saiha (550 - 700), Remaining Saiha, Lower Lunglei (300 - 550), Remaining all districts (0 - 300)

Eastern part of Tuensang, Eastern part of KiphireSadar, Eastern part of Phek (100 - 225), Remaining all districts (0 - 100)

Western part of Ganjam, Kendrapara, Jajpur, Eastern Kandhamal, Lower Angul (300 - 600), Remaining Ganjam, Remaining all districts $(0-300)$

North-western Pathankot, West TaranTaran, West Firozpur (175 250), Hoshiarpur, Kapurthala, Upper Fazilka, Moga, Upper Faridkot, Jalandhar (100 - 175), Remaining all districts (0 - 175)

Remaining all districts $(0-500)$

Upper Mahbubnagar, Eastern Warangal (200 - 350), Medak, Hyderabad, Upper Nalgonda, Lower Nizamabad (350 - 500), Remaining all districts $(0-200)$

South Tripura (50 - 100), Remaining all districts (0 - 50)

Lower Muzaffarnagar, Lower Bijnor, Bahraich, Lower Mathura, Hathras, Etah, Farrukhabad, Upper Mainpuri, Kannauj, Shravasti, Gonda, Faizabad, Sultanpur, Rae bareli, Fatehpur, Banda, Chitrakoot, Kaushambi, Pratapgarh, Jaunpur, Allahabad, Sultanpur, Upper Azamgarh,Upper Mau, Varanasi, Mirzapur, Sonbhadra, SantKabir Das Nagar, Chandauli, Ghazipur, Ballia (125 - 225), Bagpat, Meerut, Ghaziabad, JyotibaPhulenagar, Rampur, Moradabad, Gautam Buddha Nagar, Bulandshahr, Badaun, Bareilly,Pilibhit, Shahjahanpur, LakhimpurKheri, Sitapur, Hardoi, Bara Banki, Lucknow, Unnao, Kanpur, Aligarh, Upper Mathura (225 - 300), Remaining all districts (0 - 125)

Lower Uttarkashi, Central Uttarkashi, Upper border of RudraPrayag, Lower Udham Singh Nagar (200 - 350), Eastern Uttarkashi, Upper half of Chamoli, Upper half of Pithoragarh (350 500), Remaining all districts $(0-200)$

Maldah, Western part of DakshinDinajpur (100-175), Lower part of Uttar Dinajpur (175 - 250), Remaining all districts (0 - 100) 


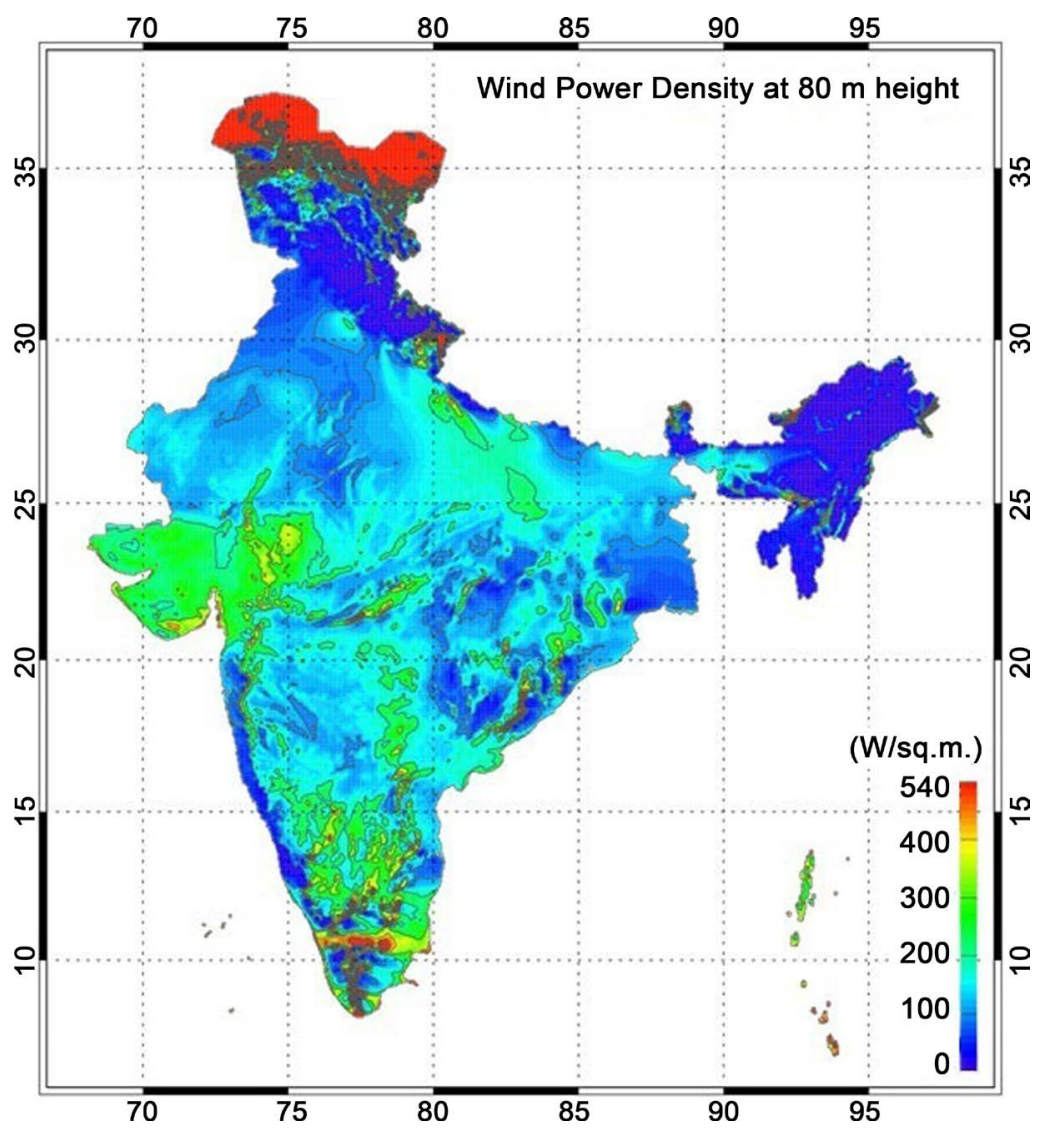

Figure 8. Wind power density map of India at $80 \mathrm{~m}$ height [15].

observed between the two is small and validates our system. It can thus be utilized for estimating the energy generation at any location. Accordingly energy generation is computed for entire country and the values are contoured for map generation. Small deviation may be because the database Meteonorm gives approximate weather average data instead of actual causing a deviation of around $5-10$ percent. The developed energy generation maps are different and more useful from the existing wind power density maps in two ways. First, energy generation maps provide exact generation potential at a particular location. Whereas the power density maps only provide with information about the wind potential based on wind speed. Also in some places the potential density maps show no potential but there is such a possibility in energy generation maps with proper advanced technology. The common similarity between the two is that there is high energy generation where there is high potential density. We have many wind power density maps at different heights but no one has so for computed for the energy generation maps for a fixed capacity and hub height of wind turbine.

\section{Acknowledgements}

Authors would like to thank Sri J. N. Singh, VCMT of Gujarat Energy Research \& Management Institute (GERMI), Gandhinagar, for being constant source of inspiration and encouraging us to share our knowledge and experience in the form of publication 
for greater benefit of the solar industry in India and abroad. We would also like to thank Mr. Prashant Gopiyani, the Coordinator of Summer Internship 2016 for all his help and would also like to thank GERMI management for lending the required software's for this research.

\section{References}

[1] Singh, M. and Singh, P. (2014) A Review of Wind Energy Scenario in India. International Research Journal of Environment Sciences, 3, 87-92. www.isca.in/IJENS/Archive/v3/i4/13.ISCA-IRJEvS-2014-52.pdf

[2] Wikipedia. https://en.wikipedia.org/wiki/Renewable_energy

[3] Make in India. http://www.makeinindia.com/sector/renewable-energy

[4] Wind Energy Foundation. http://windenergyfoundation.org/about-wind-energy/history/

[5] Keyhani, A., Ghasemi, M., Khanali, M. and Abbaszadeh, R. (2010) An Assessment of Wind Energy Potential as a Power Generation Source in the Capital of Iran, Tehran. Energy, 35, 188-201. http://www.sciencedirect.com/science/article/pii/S0360544209003958 http://dx.doi.org/10.1016/j.energy.2009.09.009

[6] Raikar, N. (2016) Indian Wind Power. Indian Wind Turbine Manufacturers Association, 2, $3-4$.

http://www.indianwindpower.com/pdf/Indian\%20Wind\%20Power,\%20April\%20-\%20May \%202016.pdf

[7] Meteonorm 7. http://www.meteonorm.com/

[8] TRNSYS 17. http://www.trnsys.com/

[9] Surfer 10. http://www.goldensoftware.com/products/surfer

[10] Nguyen, K.Q. (2007) Wind Energy in Vietnam: Resource Assessment, Development Status and Future Implications. Energy Policy, 35, 1405-413.

http://www.sciencedirect.com/science/article/pii/S0301421506001893 http://dx.doi.org/10.1016/j.enpol.2006.04.011

[11] Abbasi, S. and Abbasi, N. (2006) Renewable Energy Resources and Their Environmental Impact. https://books.google.co.in/books?isbn $=8120319028$

[12] Islam, M., Saidur, R. and Rahim, N. (2011) Assessment of Wind Energy Potentiality at Kudat and Labuan, Malaysia Using Weibull Distribution Function. Energy, 36, 985-992. http://www.sciencedirect.com/science/article/pii/S0360544210007012 http://dx.doi.org/10.1016/j.energy.2010.12.011

[13] Samantaray, B. and Patnaik, K. (2010) A Study of Wind Energy Potential in India. https://www.hitpages.com/doc/4976613502484480/1/

[14] Online Monitoring of IREDA Funded Wind Energy Projects. 2014. www.ireda.gov.in/writereaddata/Report\%20on\%20Online\%20Monitoring\%20of\%20IREDA \%20Wind\%20Energy\%20Funded\%20Projects.pdf

[15] http://www.renewablesinternational.net/wind-projects-and-economy-in-india/150/435/84942 
Submit or recommend next manuscript to SCIRP and we will provide best service for you:

Accepting pre-submission inquiries through Email, Facebook, LinkedIn, Twitter, etc. A wide selection of journals (inclusive of 9 subjects, more than 200 journals)

Providing 24-hour high-quality service

User-friendly online submission system

Fair and swift peer-review system

Efficient typesetting and proofreading procedure

Display of the result of downloads and visits, as well as the number of cited articles

Maximum dissemination of your research work

Submit your manuscript at: http://papersubmission.scirp.org/

Or contact jpee@scirp.org 